BMJ Paediatrics Open

\section{Living with epilepsy}

To cite: Chandra A. Living with epilepsy. BMJ Paediatrics Open 2019;3:e000497. doi:10.1136/ bmjpo-2019-000497

Received 5 June 2019 Accepted 6 June 2019
Check for updates

(C) Author(s) (or their employer(s)) 2019. Re-use permitted under CC BY-NC. No commercial re-use. See rights and permissions. Published by BMJ.

BGS Bristol School, Bristol, UK

Correspondence to Anoushka Chandra; achand32@ bgs.bristol.sch.uk
I am a 16 year old and I am currently in year 12 so am studying to do my A-Levels next year, and I am taking biology, chemistry, maths and psychology. I would like to pursue a career in medicine with a special interest in clinical genetics which has stemmed from my personal experiences of accessing healthcare and undergoing investigations and treatment in my local hospital Neurology department. The knowledge, care and patience demonstrated by the doctors, nurses and neurophysiologists was outstanding and this has led me to want to pursue a career in medicine.

My first experience that I remember with the National Health Service (NHS) was in 2009, when I was 6 years and admitted for almost a week following a long seizure. Therefore, the NHS is a huge part of my life, and the team of nurses and doctors were supportive. I recall the hospital education team visiting me and I also went to the hospital's radio station room, which was exciting as a young child.

Since then I have had numerous electroencephalographies (EEGs) - tests done where the electrical activity of my brain was recorded via leads on my head. The neurophysiology team were always very compassionate and took particular care when putting on and taking off the leads as glue was involved.

Two years ago, having previously well controlled epilepsy, I started to have increased seizures with no triggers. This resulted in further investigations such as an MRI, blood tests and more EEGs. The neurologist then referred me to the clinical geneticist who informed me about a project which looks at rare genetic conditions. So, 2 years ago, I was recruited as a 100000 genome participant. The process was thoroughly explained to me by my geneticist and genomic counsellor who surprisingly sparked my interest in genetics and I am currently doing an Extended Project Qualification in this area. I am currently involved with Genomics England on consultations regarding consenting children in the project, who are now turning 16.

I am a Young Ambassador with a charity called Young Epilepsy and I have been

\section{My suggestions}

Better links between the National Health Service and local charities.

- Practical advice about the impact of an illness on one's social life is essential.

- Greater use of modern technology such as skype between health professionals and young patients.

involved in drafting a survey for young people to capture their experiences and the recurring theme was the impact of their chronic condition on themselves and the people around them, in all aspects, including emotional health. Therefore, my proposition would be to have better links between the NHS and local charities, perhaps through epilepsy nurse specialists.

I am part of a youth advisory group at my local hospital where young patients have the opportunity to voice their opinions on the NHS and I recently went to a workshop where we talked about the 10-year NHS plan, the future of healthcare. The students that attend range from around 14-18 years and are from a range of private and public schools and from different cultures and backgrounds too. We meet around once a month for one and a half hours to take part in a range of activities ranging from attending a stimulation centre to discussing the atmosphere and safety of certain wards.

In terms of advice for health professionals, it is mainly positive and in my opinion, the care I receive is professional yet warm. Sometimes, the wait at clinics can sometimes be longer than my actual consultations, which can interrupt my school lessons. It is obviously very difficult to combat this; however, with the ever increasing advancement of technology, I do believe that skype calls are the way forward as it is much quicker for the patient and the professional too. Nevertheless, throughout my actual checkups and consultations, I have always felt included in my healthcare; everything is clearly explained to me and I am treated as an adult which is refreshing and I have the fullest confidence in anyone involved in my healthcare. 
Practical advice is as much important as medication for seizure, as last year, when I had more seizures; I was worried how this unpredictable condition would impact my social life, school and taking GCSEs. I received this advice from my doctor. It would nice to have better links between school, families and local support groups.

Having had excellent care in the paediatric setting, I hope I get good care when I get transferred to adult services, with good transition between the two.
Funding The authors have not declared a specific grant for this research from any funding agency in the public, commercial or not-for-profit sectors.

Competing interests None declared.

Patient consent for publication Not required.

Provenance and peer review Commissioned; internally peer reviewed.

Open access This is an open access article distributed in accordance with the Creative Commons Attribution Non Commercial (CC BY-NC 4.0) license, which permits others to distribute, remix, adapt, build upon this work non-commercially, and license their derivative works on different terms, provided the original work is properly cited, appropriate credit is given, any changes made indicated, and the use is non-commercial. See: http://creativecommons.org/licenses/by-nc/4.0/. 